Historic, Archive Document

Do not assume content reflects current scientific knowledge, policies, or practices. 


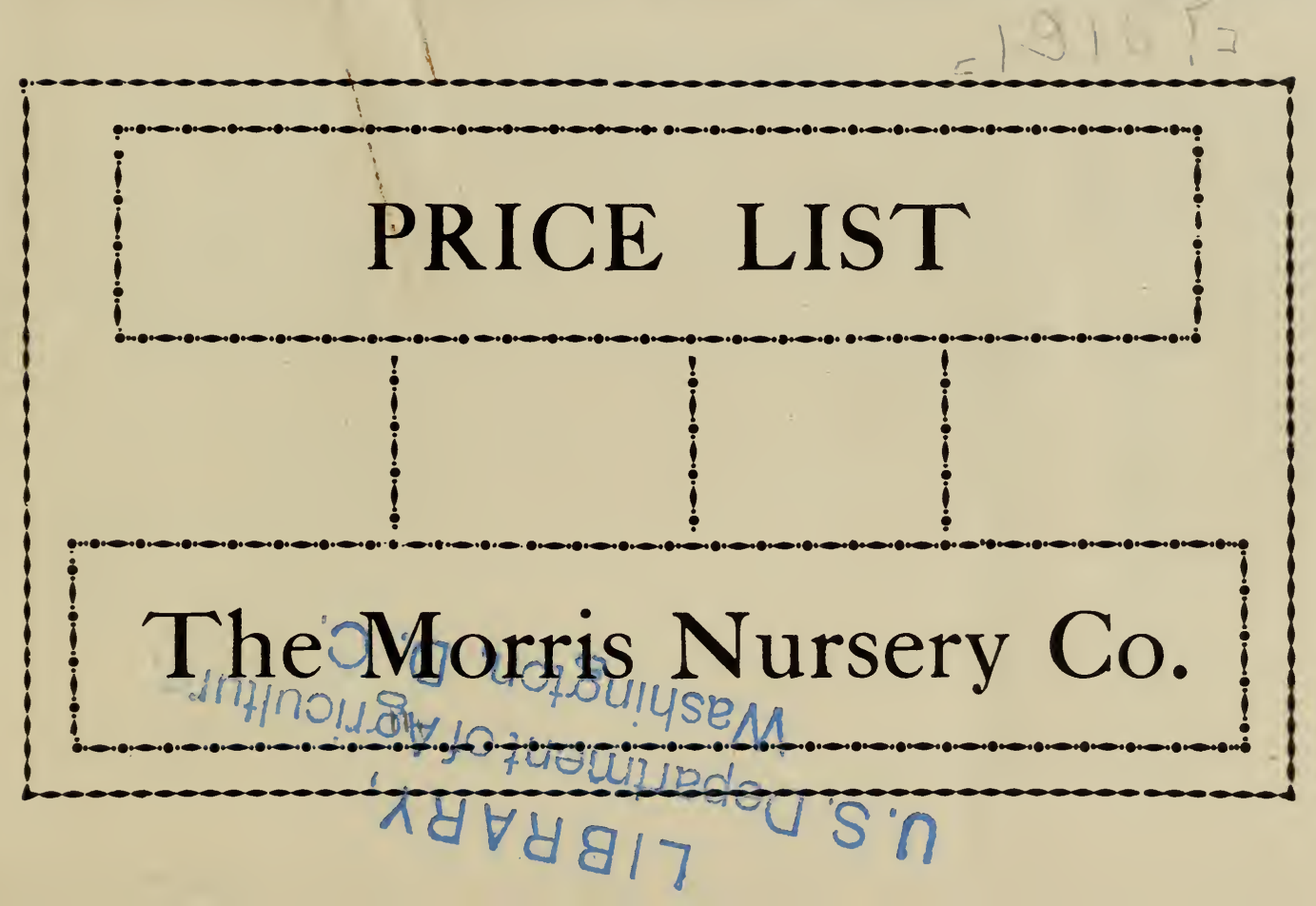





\section{FRUIT TREES}

The sizes given below are such as are generally sold. We sometimes have larger trees in stock at increased prices.

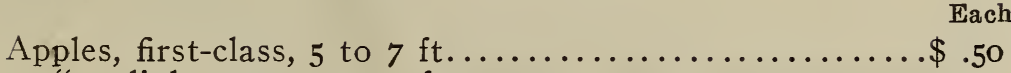

light stem, 4 to $5 \mathrm{ft} \ldots \ldots \ldots \ldots \ldots \ldots \ldots \ldots \ldots . .25$

Crabapples, same price as Apples.

Per doz. Per 100

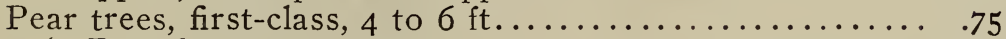

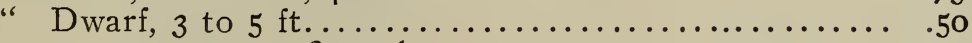

Cherry trees, sweet, first-class.................. .75

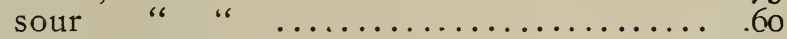

Peach trees, first-class, 4 to $6 \mathrm{ft} \ldots \ldots \ldots \ldots \ldots \ldots \ldots \ldots \ldots \ldots . .30$

$\$ 5.00 \quad \$ 35.00$

$2.50 \quad 20.00$

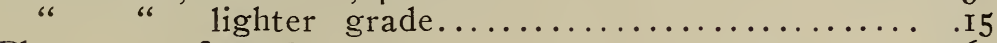

Plum trees, first-class........................ 60

Apricots, first-class $\ldots \ldots \ldots \ldots \ldots \ldots \ldots \ldots \ldots \ldots \ldots \ldots \ldots . .35$

Nectarines, first-class $\ldots \ldots \ldots \ldots \ldots \ldots \ldots \ldots \ldots \ldots \ldots \ldots . .35$

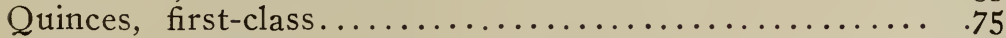

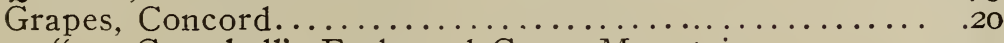

"Campbell's Early and Green Mountain.......... .50

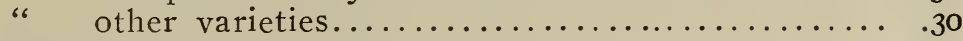

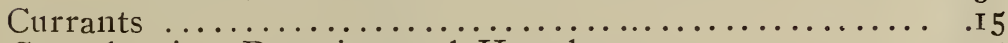

Gooseberries, Downing and Houghton..............25

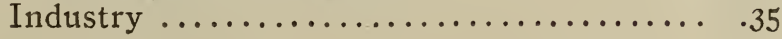

7.50

5.00

7.50

6.00

3.00

I. 50

6.00

3.50

3.50

7.50

2.00

5.00

3.00

I. 50

2.50

3.50

I6.00

I0.00 
Asparagus, $\$ 8.00$ per Iooo.

\section{ORNAMENTAL DEPARTMENT}

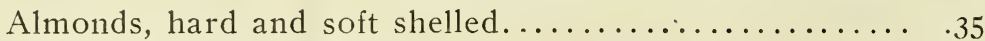

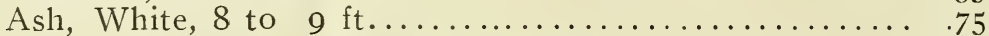

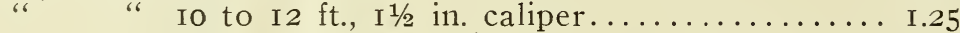

12.00

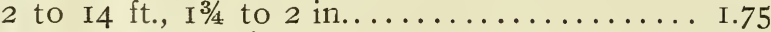

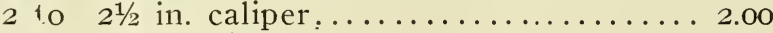

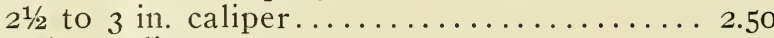

I8.00

20.00

3 in. caliper................... 3.00

Beech, English, 6 to $8 \mathrm{ft} \ldots \ldots \ldots \ldots \ldots \ldots \ldots \ldots \ldots \ldots \ldots$

25.50

30.00

10.00

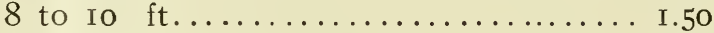

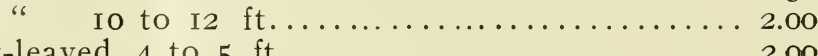

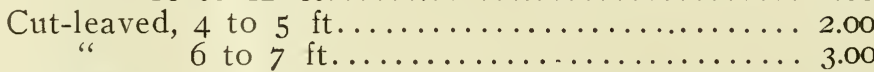

15.00

20.00

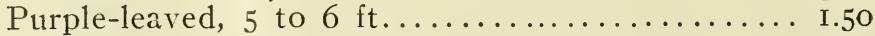

15.00

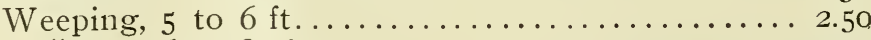

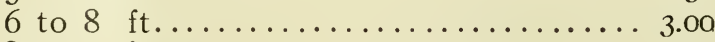

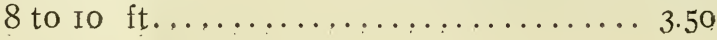




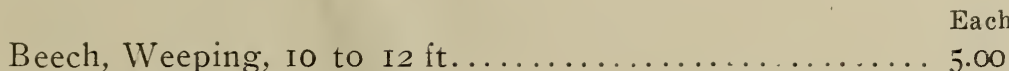

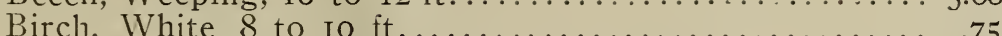

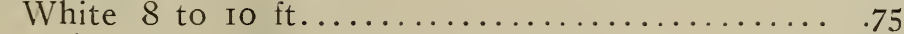

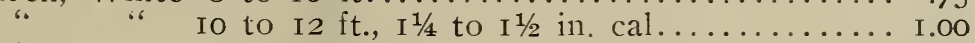

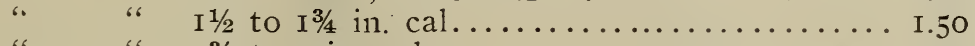

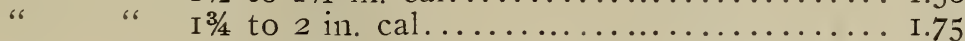

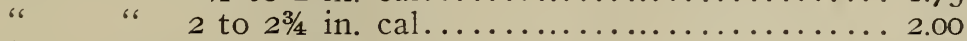

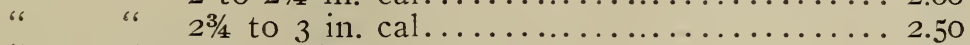

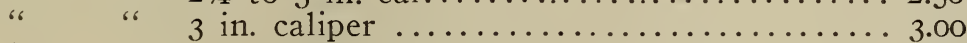

" " 4 in. caliper .................. 4.00

"Cut-leaved Weeping, 5 to $6 \mathrm{ft} \ldots \ldots \ldots \ldots \ldots \ldots \ldots$ I.5O

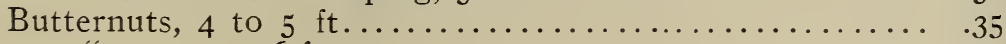

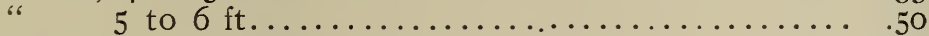

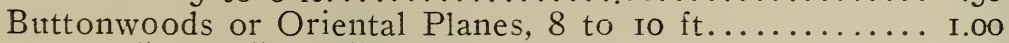

$\begin{array}{lll}66 & 6 & 6 \\ 66 & 6 & 66 \\ 66 & 6 & 6 \\ 66 & 66 & 6\end{array}$

" Io to I2 ft...

. 1.25

I2 to I4 ft........... I.5O

I4 $\mathrm{I} 3 / 4$ in $\ldots \ldots \ldots \ldots \ldots .2 .00$

2 to $2 \frac{1}{2}$ in. cal......... 2.25

" $2 \frac{1}{2}$ to 3 in. cal......... 2.50

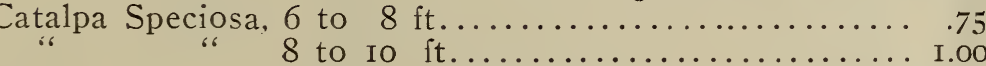

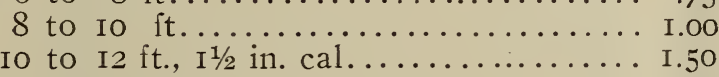

Kaempferi, 5 to $6 \mathrm{ft} . \ldots \ldots \ldots \ldots \ldots \ldots \ldots$..co

I0.00

I 5.00

20.00

32.00

6.00

I0.00

I 5.00

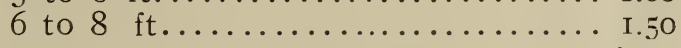


Catalpa Bungii, Each

Catalpa Bungii, 4 to $6 \mathrm{ft}$.......

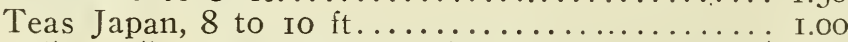

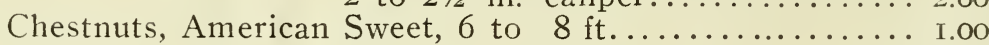

8 to so $\mathrm{ft} \ldots \ldots \ldots \ldots \ldots \ldots \ldots \ldots$ I. 50

Paragon, 4 to $6 \mathrm{ft} \ldots \ldots \ldots \ldots \ldots \ldots \ldots \ldots \ldots$

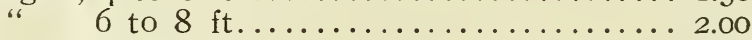

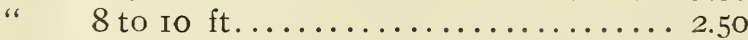

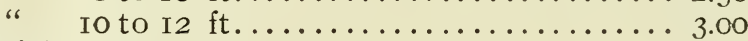

Spanish 4 to $5 \mathrm{ft} \ldots \ldots \ldots \ldots \ldots \ldots \ldots \ldots \ldots . . . \ldots \ldots$

" 5 to $6 \mathrm{ft} \ldots \ldots \ldots \ldots \ldots \ldots \ldots \ldots \ldots$

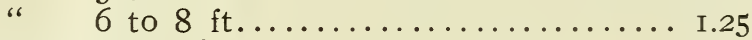

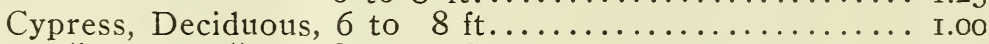

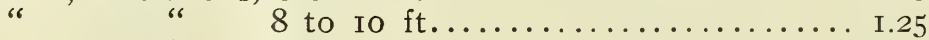

" Io to I2 $\mathrm{ft} \ldots \ldots \ldots \ldots \ldots \ldots \ldots \ldots \ldots \ldots$

Dogwood, White-flowering, 5 to $6 \mathrm{ft} \ldots \ldots \ldots \ldots \ldots \ldots \ldots .75$

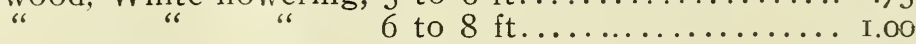

Red-flowering 3 to $4 \mathrm{ft} \ldots \ldots \ldots \ldots \ldots \ldots \ldots \ldots$..oo

" $" 4$ to $5 \mathrm{ft} \ldots \ldots \ldots \ldots \ldots \ldots \ldots \ldots \ldots$ I.50

Weeping, 3 to $4 \mathrm{ft} \ldots \ldots \ldots \ldots \ldots \ldots \ldots \ldots \ldots$

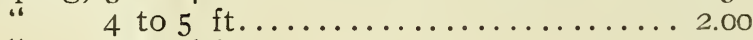

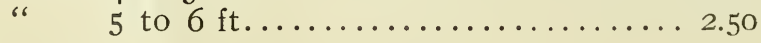


Elms, American, 8 to ro $\mathrm{ft} . \ldots \ldots \ldots \ldots \ldots \ldots \ldots \ldots \ldots$ I.00

Io to $\mathrm{I} 2 \mathrm{ft} ., \mathrm{I} \frac{1}{2} 2$ in. cal.............. I.25

I 2.00

Golden, 5 to $6 \mathrm{ft}$.

I 2 ft., I $3 / 4$ in. cal................... I.50

I5.00

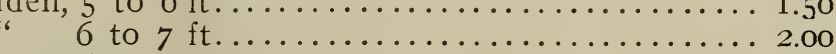

Filbert or Hazelnut, 4 to $5 \mathrm{ft} \ldots \ldots \ldots \ldots \ldots \ldots \ldots \ldots . .50$

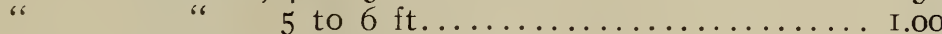

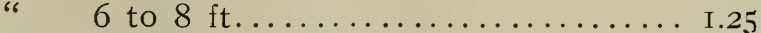

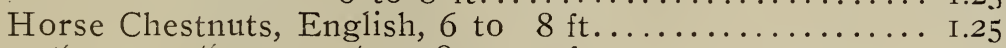

8 to ro $\mathrm{ft} . \ldots \ldots \ldots \ldots \ldots \ldots \ldots$ I.50

" " " Double-flowering, 8 to io $\mathrm{ft} \ldots \ldots \ldots \ldots . . .50$

" " Red-flowering, 5 to $6 \mathrm{ft} \ldots \ldots \ldots \ldots \ldots \ldots 2.00$

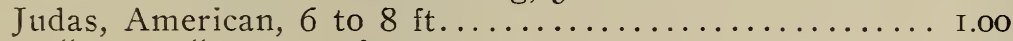
" " Am "
Io $\mathrm{ft}$
I. 25

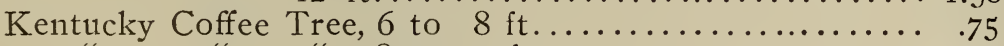

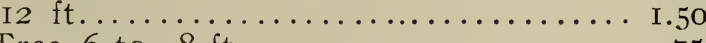
" " " 8 to ro ft................. I.25

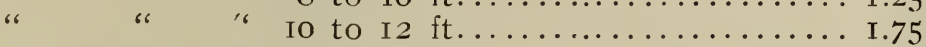

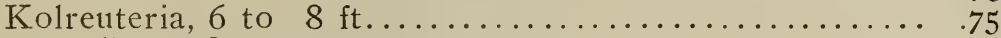

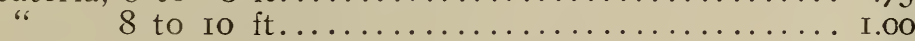

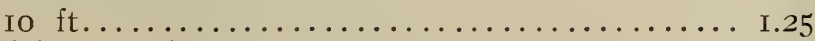

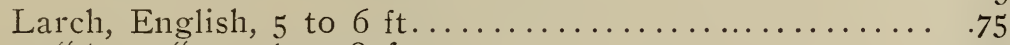
" 6 to $8 \mathrm{ft}$.
1.00 


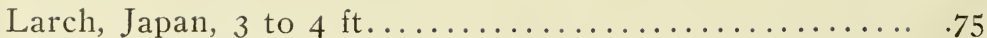

Laburnum, Golden Chain, 6 to $8 \mathrm{ft} \ldots \ldots \ldots \ldots \ldots \ldots .75$

" " " 8 to Io $\mathrm{ft} \ldots \ldots \ldots \ldots \ldots \ldots \ldots \ldots$.

" " " " 0 to I2 $\mathrm{ft} \ldots \ldots \ldots \ldots \ldots \ldots \ldots \ldots$ I.25

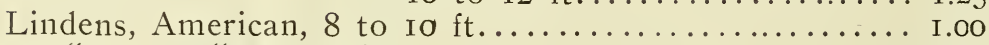

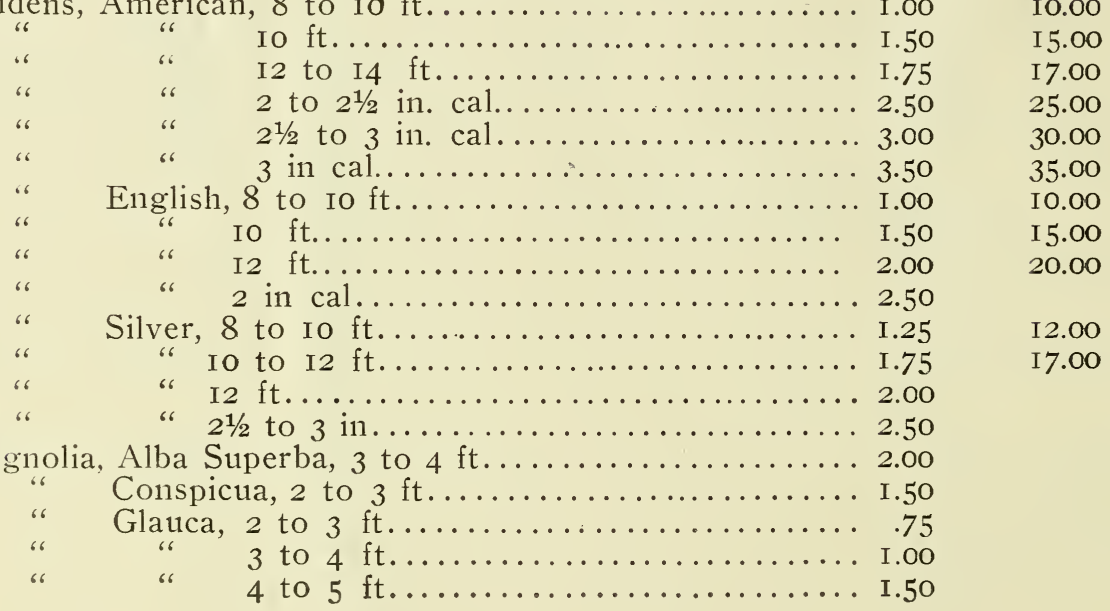

10.00

5.00

7.00

25.00

30.00

5.00

0.00

5.00

I 2.00

7.00

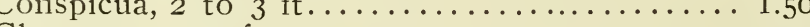

auca, 2 to 3 ft.......

" 4 to $5 \mathrm{ft} . \ldots \ldots \ldots \ldots \ldots \ldots \ldots \ldots$ I.50 


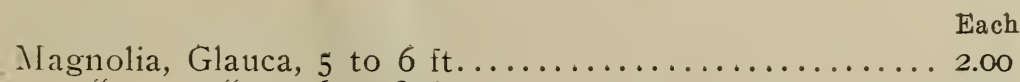

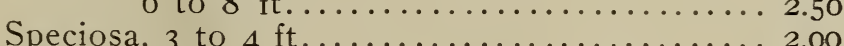

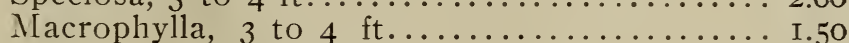

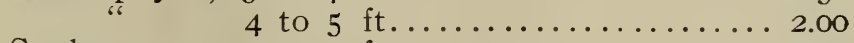

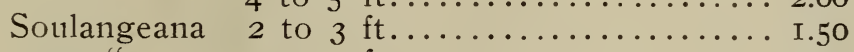

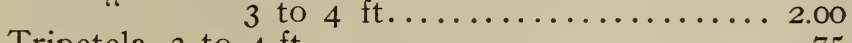

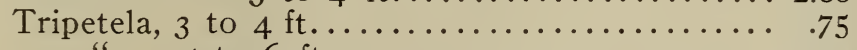

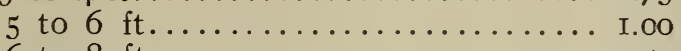

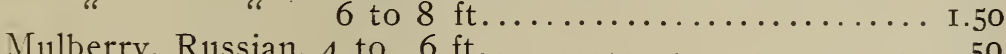

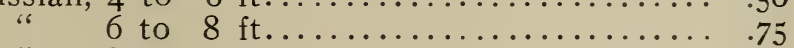

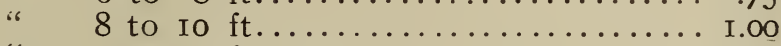

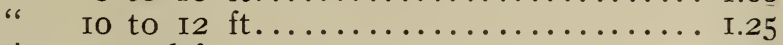

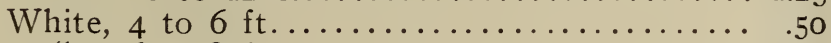

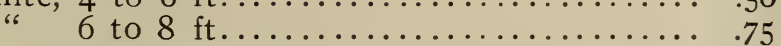

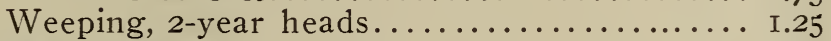

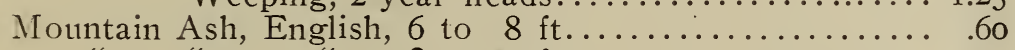

Maples, Ash-leaved, 8 to ro ft.................75 7.50 


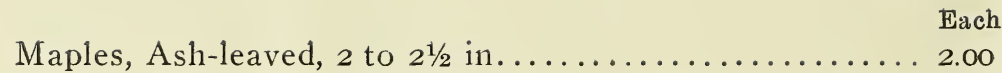

Per doz. Per 100

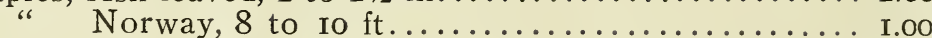

" " "

I2 to I4 ft................... I

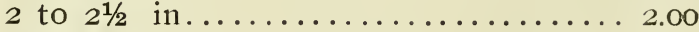

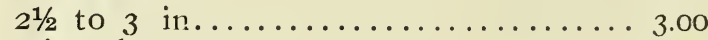

3 in cal......................... 4.00

4 in. cal.......................... 5.00

5 in cal..................... 6.00

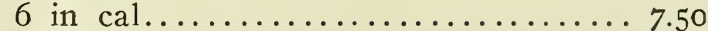

66

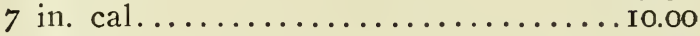

Silver, 8 to ro $\mathrm{ft} \ldots \ldots \ldots \ldots \ldots \ldots \ldots \ldots \ldots \ldots . .75$

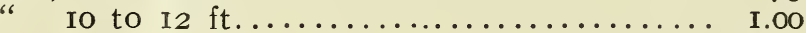

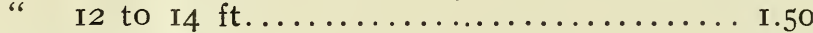

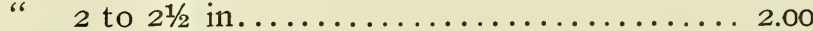

Schwedleri, 6 to $8 \mathrm{ft} \ldots \ldots \ldots \ldots \ldots \ldots \ldots \ldots$ r.50

" 8 to ro $\mathrm{ft} \ldots \ldots \ldots \ldots \ldots \ldots \ldots \ldots \ldots . \ldots \ldots$

Wier's Cut-leaved, 8 to ro $\mathrm{ft} . \ldots \ldots \ldots \ldots \ldots \ldots \ldots .75$

" " ro to $12 \mathrm{ft} \ldots \ldots \ldots \ldots \ldots \ldots$ I.00

" " $"$ I2 to I4 ft............... I.50

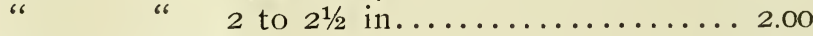

Sugar, 8 to ro ft.................... .75

Io to $\mathrm{I} 2 \mathrm{ft} \ldots \ldots \ldots \ldots \ldots \ldots \ldots \ldots \ldots \ldots \ldots \ldots$

10.00

I 2.00

15.00

20.00

30.00

40.00

50.00

60.00

75.00

$7 \cdot 50$

10.00

I 5.00

I 5.00

7.50

IO.00 


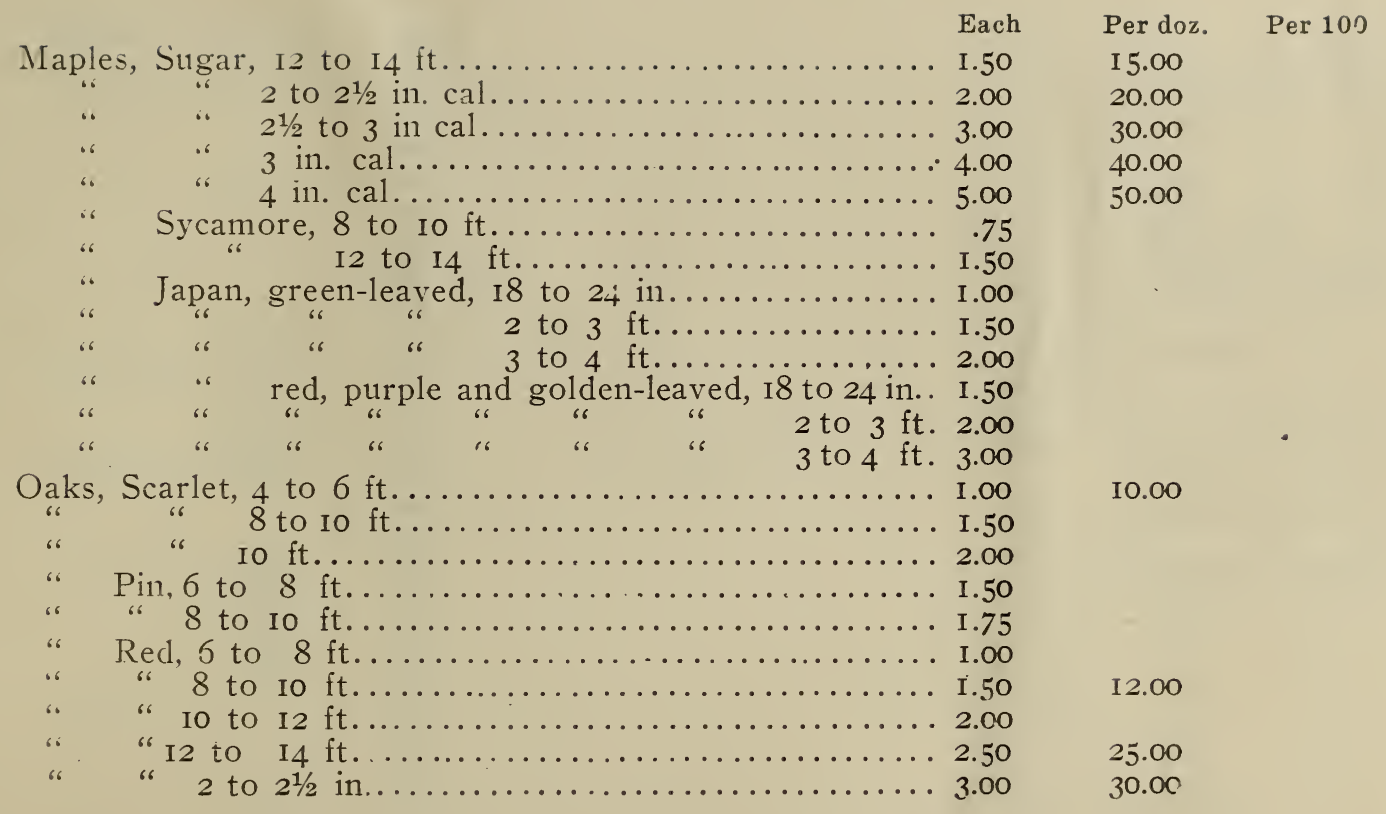


Oaks, Red, 3 in. cal......................... 4.00

Turkey, 8 to io $\mathrm{ft} \ldots \ldots \ldots \ldots \ldots \ldots \ldots \ldots \ldots \ldots$ I. 50

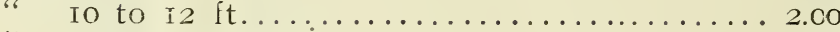

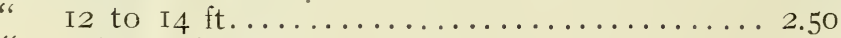

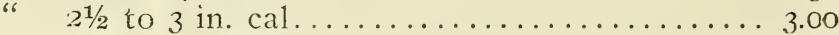

Pyramidal, 5 to $6 \mathrm{ft} \ldots \ldots \ldots \ldots \ldots \ldots \ldots$ I. 50

Prunus Triloba, 2 to $3 \mathrm{ft} \ldots \ldots \ldots \ldots \ldots \ldots \ldots \ldots \ldots \ldots \ldots \ldots \ldots \ldots \ldots . .50$

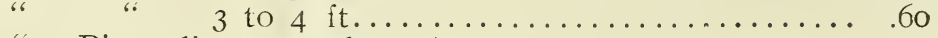

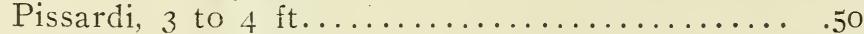

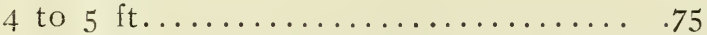

5 to $6 \mathrm{ft} \ldots \ldots \ldots \ldots \ldots \ldots \ldots \ldots \ldots \ldots$ I. 25

Peach, Double flow., pink, white, scarlet, 4 to $5 \mathrm{ft} \ldots \ldots .50$

$$
\text { " " " " " } 3 \text { to } 4 \text { ft...... .30 }
$$

Persimmons, 4 to $5 \mathrm{ft}$

$\begin{array}{ccc}3 \text { to } 4 \mathrm{ft} \ldots \ldots \ldots & .30 \\ \ldots \ldots \ldots \ldots & .50\end{array}$

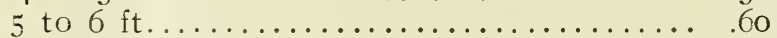

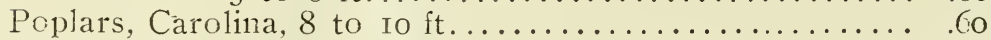

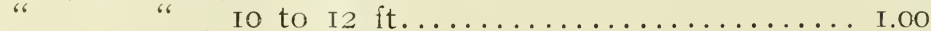

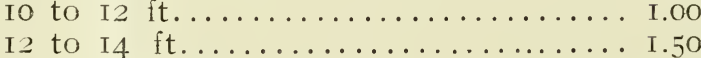

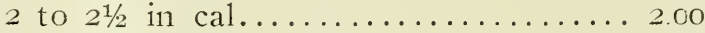

$2 \frac{1}{2}$ to 3 in. cal...................... 2.50

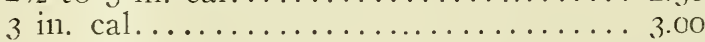

4 in cal ...................... 4.00

Lombardy, 8 to io $\mathrm{ft} \ldots \ldots \ldots \ldots \ldots \ldots \ldots \ldots .60$

5.00

7.50

I 2.00

5.00

3.00

6.00

IO.CO

I 5.00

20.00

6.co 
Each

Poplars, Lombardy, io to $12 \mathrm{ft}$.

I 2 to $\mathrm{I} 4 \mathrm{ft}$.

2 to 3 in. cal.

Bolleana, 8 to Io $\mathrm{ft}$.

I.50

2.00

I.00

1.50

IO to I2 $\mathrm{ft}$...

I.75

“ I2 to I4 ft. .

2 in. cal..........................

Trichocarpa, 4 to $6 \mathrm{ft} \ldots \ldots \ldots \ldots \ldots \ldots \ldots \ldots .75$

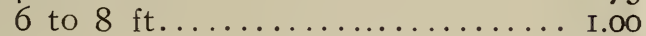

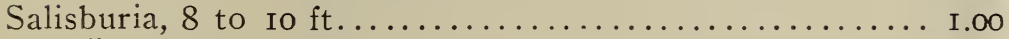

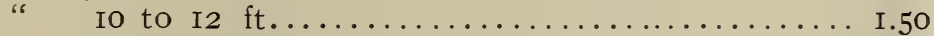

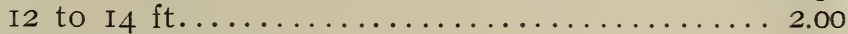

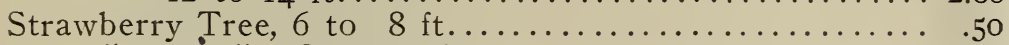

" " 8 to Io $\mathrm{ft} \ldots \ldots \ldots \ldots \ldots \ldots \ldots \ldots \ldots .75$

" " I0 to I2 $\mathrm{ft} \ldots \ldots \ldots \ldots \ldots \ldots \ldots \ldots \ldots$ I.25

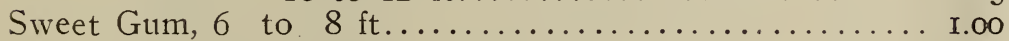

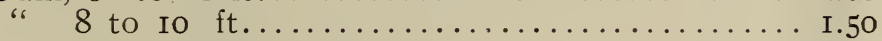

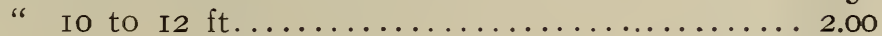

" I2 to I4 ft. $\ldots \ldots \ldots \ldots \ldots \ldots \ldots \ldots \ldots \ldots \ldots \ldots \ldots, 2.50$

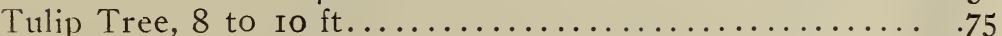

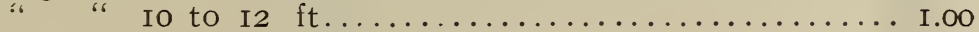

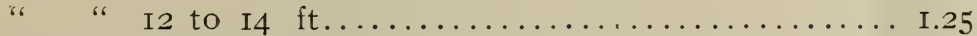

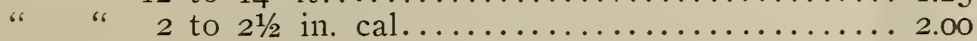

Per doz.

10.00

15.00

I0.00

I 5.00

5.00

$7 \cdot 50$

I0.00

I 2.00

20.00

7.50

I0.00

I 2.00

20.00 
Tulip Tree, $2 \frac{1 / 2}{2}$ to 3 in. cal......................... Each

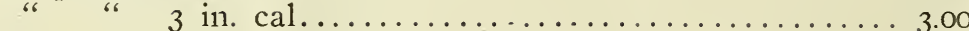

\subsection{0}

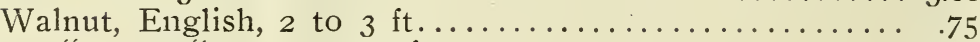

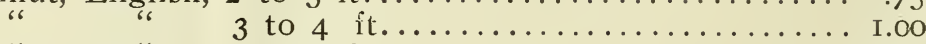

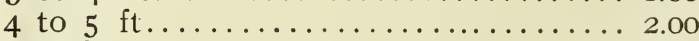

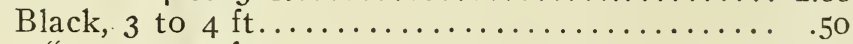

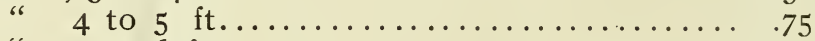

" 5 to $6 \mathrm{ft} \ldots \ldots \ldots \ldots \ldots \ldots \ldots \ldots \ldots \ldots \ldots \ldots$.

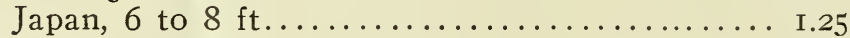

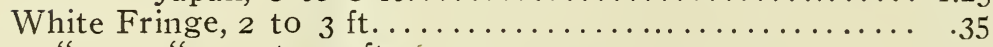

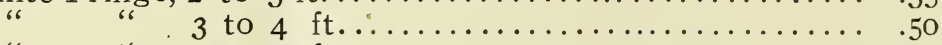

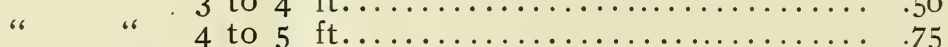

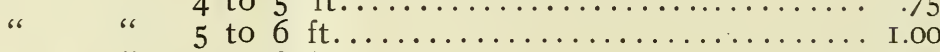

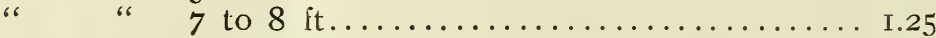

Willows, Babylonian, 8 to ro $\mathrm{ft} \ldots \ldots \ldots \ldots \ldots \ldots \ldots \ldots .75$

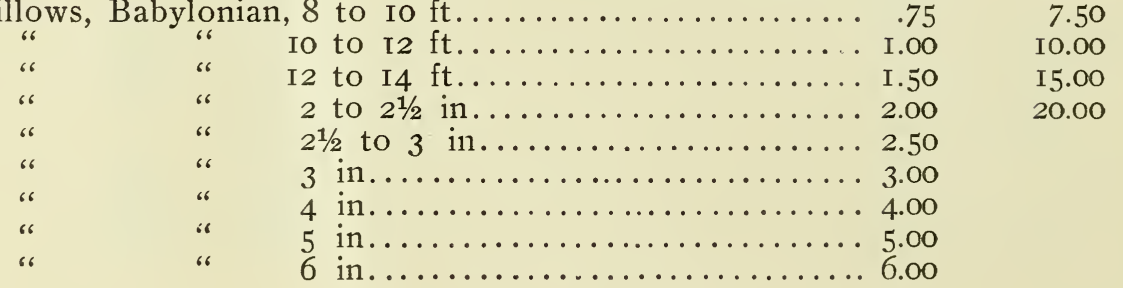

$7 \cdot 50$

I0.00

5.00

7.50

$3 \cdot 50$

5.00

7.50

I0.00

12.00

7.50

0.00

I 5.00

2 to $2^{1 / 2}$ in $\ldots \ldots \ldots \ldots \ldots \ldots \ldots \ldots \ldots . \ldots \ldots$

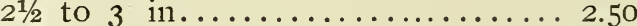

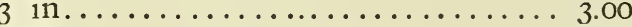

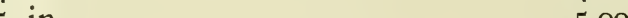

6 in ....................... 6.00 
Willows, Kilmornock ....................... 1.00

Laurel-leaved, 6 to $8 \mathrm{ft} \ldots \ldots \ldots \ldots \ldots \ldots \ldots \ldots \ldots \ldots$

" " 8 to ro $\mathrm{ft} \ldots \ldots \ldots \ldots \ldots \ldots \ldots \ldots$,

" " Io to I2 $\mathrm{ft} \ldots \ldots \ldots \ldots \ldots \ldots \ldots$ I.5O

Salomoni, 8 to Io $\mathrm{ft} \ldots \ldots \ldots \ldots \ldots \ldots \ldots \ldots \ldots, .75$

" Io to I2 ft................... I.00

" I2 to I4 $\mathrm{ft} \ldots \ldots \ldots \ldots \ldots \ldots \ldots \ldots$ I.5O

" $\quad 2$ to $2^{1 / 2}$ in. cal .................. 2.00

" $\quad 2^{1 / 2}$ to 3 in ..................... 2.50

" $\quad 3$ in. cal..................... 3.00

" 4 in. cal.................... 4.00

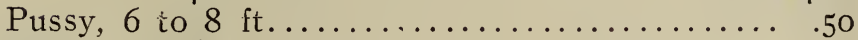

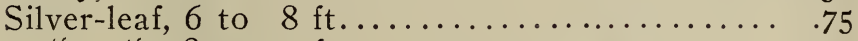

8 to ro $\mathrm{ft} \ldots \ldots \ldots \ldots \ldots \ldots \ldots$. I.00

\section{EVERGREENS.}

Arbor Vitæ, American, I2 to I5 inch tpl............... .20

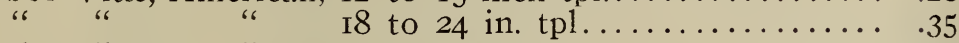

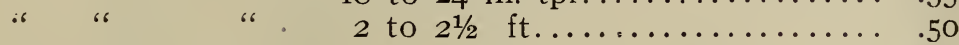

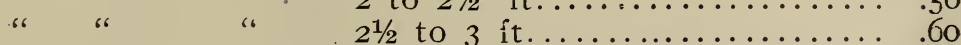

" " " $\quad 3$ to $4 \mathrm{ft}$, root pruned, bishy.... I.o

" " "

"

4 to $5 \mathrm{ft}$. , "

Compacta,

5 it........................ 1.50

I2 to 15 in $\ldots \ldots \ldots \ldots \ldots \ldots \ldots . .30$

$7 \cdot 50$

I0.00

7.50

10.00

15.00 


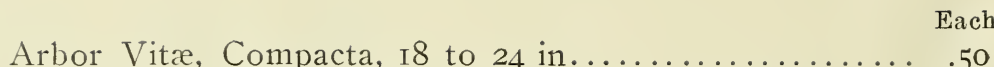

Per doz. Per 100

Arbor

5.00

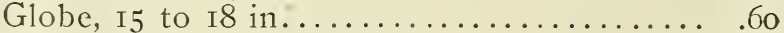

Elegantissima, I8 to 24 in............. .75

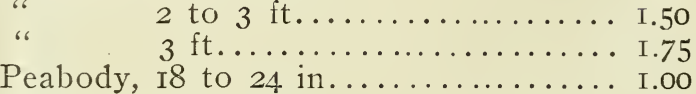

Geo. Peabody, $\begin{gathered}2 \\ \text { I8 } 8 \text { to } 24 \text { in } 2 \ldots \ldots \ldots \ldots \ldots \ldots \ldots \ldots \ldots \ldots \ldots \ldots \ldots \ldots\end{gathered}$

" " 2 to $3 \mathrm{ft} \ldots \ldots \ldots \ldots \ldots \ldots$. .75

Hovey's Golden, I2 to I8 in............ .50

" " Is to. 24 in .............

Lobbi, 2 to $2 \frac{1}{2} \mathrm{ft} . \ldots \ldots \ldots \ldots \ldots \ldots \ldots \ldots$.

Pyramidalis, 18 to $24 \mathrm{in} \ldots \ldots \ldots \ldots \ldots \ldots .50$

" 2 to $3 \mathrm{ft} \ldots \ldots \ldots \ldots \ldots \ldots .75$

" 3 to $4 \mathrm{ft} \ldots \ldots \ldots \ldots \ldots \ldots \ldots$. 25

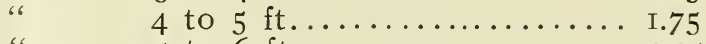

،

1.75
2.25

Siberian, I8 to 24 in ................ .75

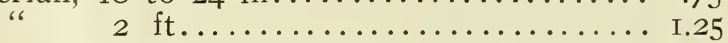

Tom Thumb, I2 to I5 in............. 50

" 8 in $\ldots \ldots \ldots \ldots \ldots \ldots \ldots \ldots \ldots .75$

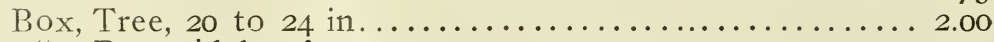

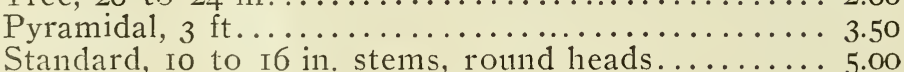

5.00

$7 \cdot 50$

5.00

7.50

I 2.00

$\mathrm{I} 7 \cdot 50$

$7 \cdot 50$

5.00

7.50

"Standard, ro to I6 in. stems, round heads........ 5.00 
Each

Cupressus Lawsoniana Allumi, $2 \mathrm{ft}$

Per doz. Per 100

Triumph de Boskoop, $3 \mathrm{ft}$

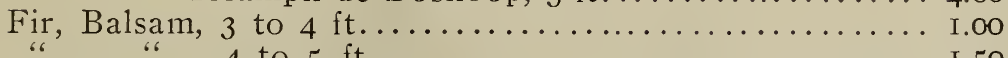

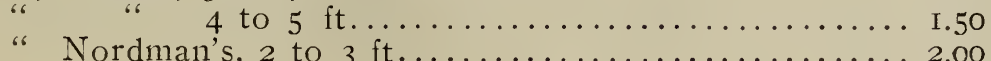

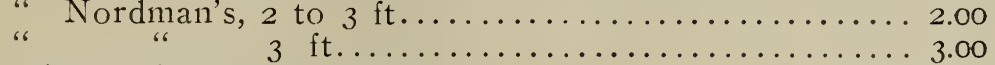

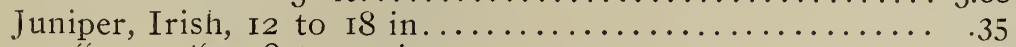

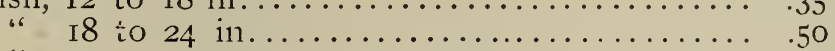

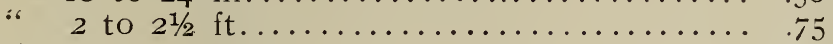

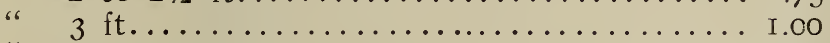

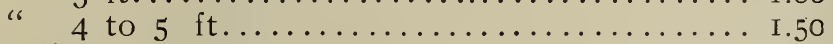

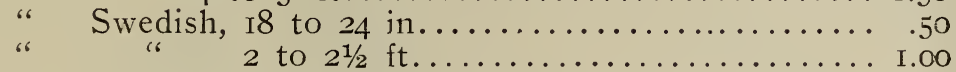

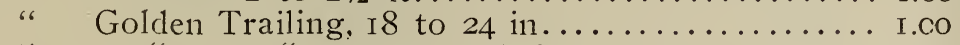

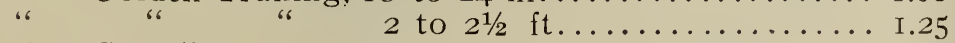

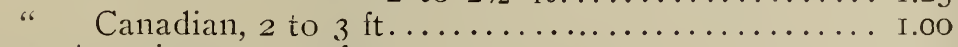

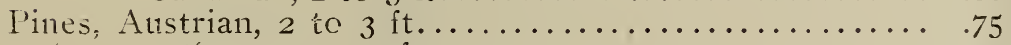

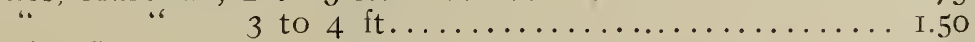

Scotch, 3 ft.........................

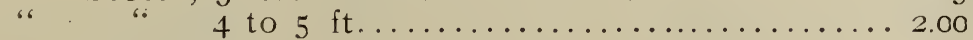

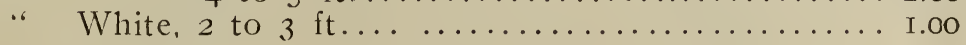




\section{EVERGREEN AND DECIDUOUS SHRUBS}

Alder, Black, 2 to $3 \mathrm{ft}$

Each

Almonds, Double White and Pink, 2 to $3 \mathrm{ft} \ldots \ldots \ldots \ldots . .35$

Altheas, Bicolor, Double White, Single White, Pæoniflora,

“ Double Purple, Variegated, Jeanne d'Arc, Red,

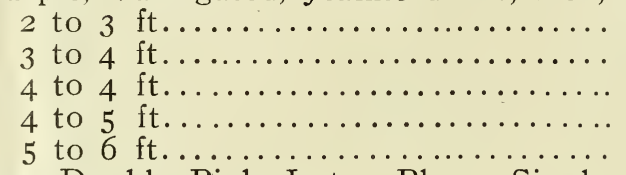

Single Blue, Double Pink, Luteo Pleno, Single

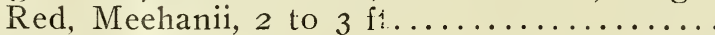

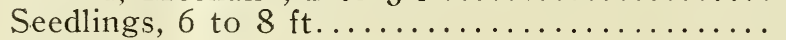
Tree Form.

6

Amorpha fragrans, 3 to $4 \mathrm{ft} \ldots \ldots \ldots \ldots \ldots \ldots \ldots \ldots \ldots . .30$

$$
\text { " }
$$$$
4 \text { to } 5 \mathrm{ft}
$$

Andromeda arborea, is to $24 \mathrm{in}$

Aralia Spinosa, 6 to $8 \mathrm{tf}$

Azalea amoena, i2 to ${ }_{5} \mathrm{in.}$

" viscosca, I8 in .

mollis, I8 in

Berberry, Purple, 2 to $3 \mathrm{ft}$.
20.00 30.00 50.00 50.00 


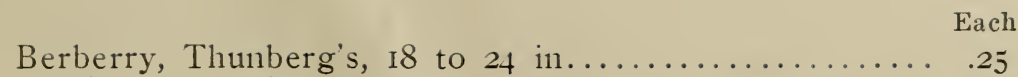$$
2 \text { to } 3 \mathrm{ft}
$$

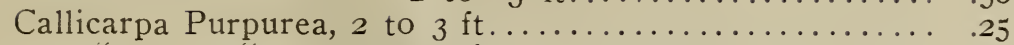

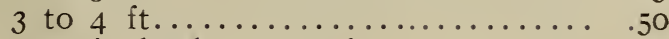

Calycanthus, Sweet-scented, shrub, 2 to $3 \mathrm{ft} \ldots \ldots \ldots \ldots \ldots . .25$

" " 3 to $4 \mathrm{ft} \ldots \ldots \ldots \ldots \ldots . .50$

Craetegus, Flowering Thorn, Double Pink, White and

Scarlet, 2 to $3 \mathrm{ft} \ldots \ldots \ldots \ldots \ldots \ldots \ldots \ldots .6 .6$

3 to $4 \mathrm{ft} \ldots \ldots \ldots \ldots \ldots \ldots \ldots \ldots \ldots \ldots \ldots \ldots \ldots \ldots \ldots . .75$

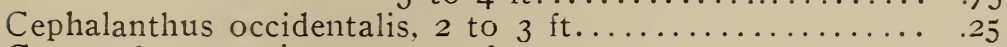

Ceonanthus americana, 2 to $3 \mathrm{ft} \ldots \ldots \ldots \ldots \ldots \ldots \ldots \ldots . .25$

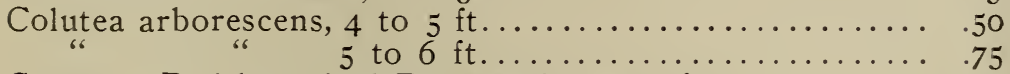

Cornus.-Red-branched Dogwood 2 to $3 \mathrm{ft} \ldots \ldots \ldots \ldots \ldots . .25$

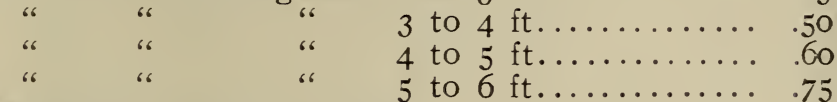

Mascula, Cornelian Cherry, 2 to $3 \mathrm{ft} \ldots \ldots \ldots \ldots . .35$

Stolonifera aurea, 2 to $3 \mathrm{ft} . \ldots \ldots \ldots \ldots \ldots \ldots . .35$

Deutzia Crenata, Candidissima, Pride of Rochester,

Scabra, Crenata fl. pl., 2 to $3 \mathrm{ft} \ldots \ldots \ldots \ldots \ldots \ldots \ldots .25$

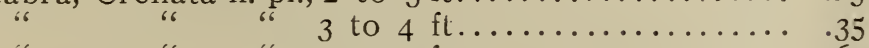

"،

3 to $4 \mathrm{ft} \ldots \ldots \ldots \ldots \ldots \ldots \ldots \ldots \ldots \ldots \ldots \ldots \ldots . .35$

4 to $5 \mathrm{ft} . \ldots \ldots \ldots \ldots \ldots \ldots \ldots .6 \ldots$

2.50

20.00

2.50

5.00

20.00

$3 \cdot 50$

2.50

20.00

3.50

6.00

25.00 
Deutzia Crenata, Candidissima, Pride of Rochester,

Scabra, Crenata fl. pl., 5 to $6 \mathrm{ft} . \ldots \ldots \ldots \ldots \ldots \ldots \ldots . .75$

" " " 6 to $7 \mathrm{ft} \ldots \ldots \ldots \ldots \ldots \ldots \ldots$ I.00

" Gracilis, Lemoine and Lemoine Compacts, $2-3 \mathrm{ft} . \quad \begin{gathered}1.00 \\ .35\end{gathered}$

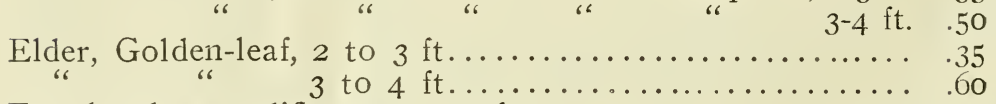

Exochorda grandiflora, 3 to $4 \mathrm{ft} \ldots \ldots \ldots \ldots \ldots \ldots \ldots . .50$

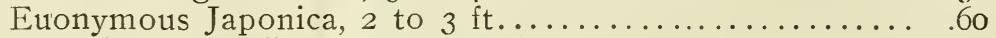

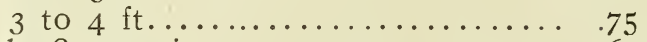

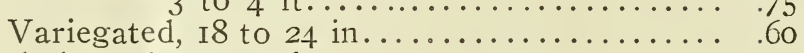

Filbert, Purple-leaved, 2 to $3 \mathrm{ft} \ldots \ldots \ldots \ldots \ldots \ldots \ldots \ldots \ldots .75$

" " 3 to $4 \mathrm{ft} \ldots \ldots \ldots \ldots \ldots \ldots \ldots \ldots \ldots$..00

Forsythia, Viridissima, Fortuni, Intermida and Sus-

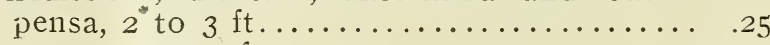

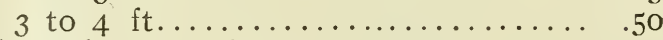

" Golden-leaved, 3 to $4 \mathrm{ft} \ldots \ldots \ldots \ldots \ldots \ldots \ldots \ldots . .50$

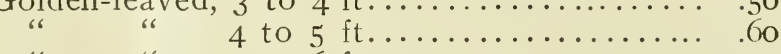

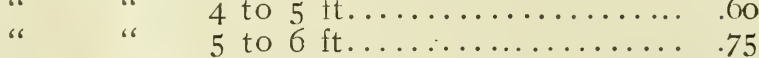

Halesia Tetraptera, 2 to $3 \mathrm{ft} \ldots \ldots \ldots \ldots \ldots \ldots \ldots \ldots \ldots . .30$

Hamamelis Virginica, 2 to $3 \mathrm{ft} \ldots \ldots \ldots \ldots \ldots \ldots \ldots \ldots . . .30$

Highbush Cranberry, 3 to $4 \mathrm{ft} . \ldots \ldots \ldots \ldots \ldots \ldots \ldots \ldots . .50$

" " 4 to $5 \mathrm{ft} \ldots \ldots \ldots \ldots \ldots \ldots \ldots \ldots \ldots .60$

" " 5 to $6 \mathrm{ft}$.

$\begin{array}{ll}2.50 & 20.00 \\ 5.00 & 40.00 \\ 5.00 & 40.00 \\ 6.00 & \\ 7.50 & \end{array}$

3.50

5.00

3.50

6.00

6.00

7.50

25.00

$7 \cdot 50$ 
Honeysuckle, upright growing, Red, White, Yellow, Morrowi, Fragrantissima and Coccinea, $2-3 \mathrm{ft}$.

3-4 ft.

Hydiang

Hypericum prolificum, 2 to $3 \mathrm{ft} \ldots \ldots \ldots \ldots \ldots \ldots \ldots . .25$

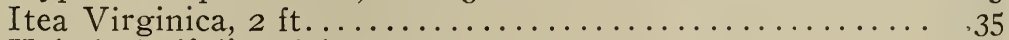

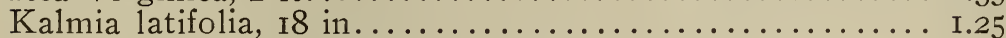

Kerria Japonica, double flowering, 2 to $3 \mathrm{ft} \ldots \ldots \ldots \ldots . .35$

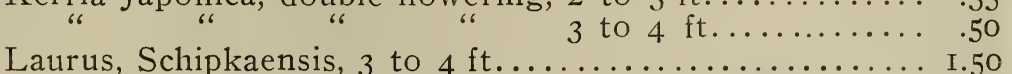

Lilacs, Common Purple and White, Persian Purple and

Persian White, 2 to $3 \mathrm{ft} \ldots \ldots \ldots \ldots \ldots \ldots \ldots . .25$

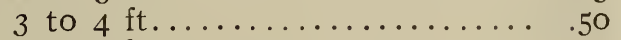

4 to $5 \mathrm{ft} \ldots \ldots \ldots \ldots \ldots \ldots \ldots \ldots . .75$

“ President Grevy, Japonica, Ludwig Spath, Marie

20.00 Legraye, Madam Lemoine, Villosa and Vir-

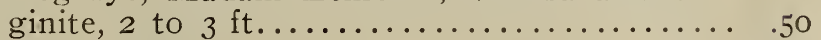

Magnolia Purpurea, 3 to $4 \mathrm{ft}$. 


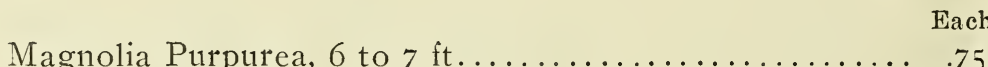

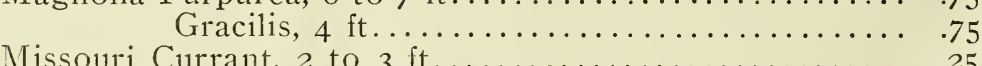

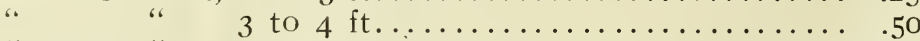

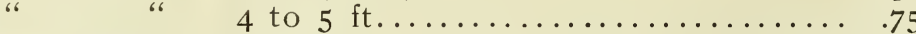

Philadelphus, Coronarius, Grandiflora, Golden and Doun-

ble flowering, 2 to $3 \mathrm{ft} \ldots \ldots \ldots \ldots \ldots \ldots . .25$

3 to $4 \mathrm{ft} \ldots \ldots \ldots \ldots \ldots \ldots .5 \%$

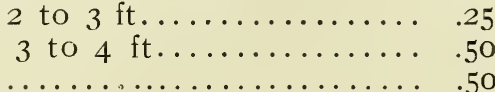

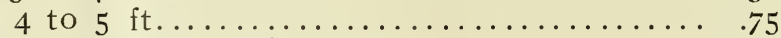

Rhododendrons, named varieties, i $8 \mathrm{in} \ldots \ldots \ldots \ldots \ldots \ldots$. .50

$2 \mathrm{ft} \ldots \ldots \ldots \ldots \ldots \ldots+2.00$

Rhodotypus kerroides, 2 to $3 \mathrm{ft} \ldots \ldots \ldots \ldots \ldots \ldots \ldots \ldots .25$

" 3 to $4 \mathrm{ft} \ldots \ldots \ldots \ldots \ldots \ldots \ldots \ldots . .50$

Rhus, Looymansi Ailanthus, tree form, 8 to Io $\mathrm{ft} \ldots . . \ldots$..oo

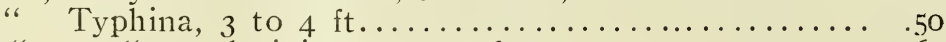

laciniata, 3 to $4 \mathrm{ft} \ldots \ldots \ldots \ldots \ldots \ldots .6 .60$

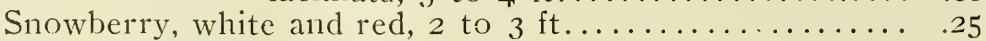

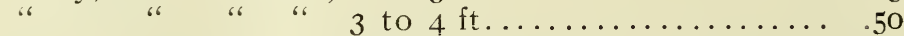

Ste 4 to $5 \mathrm{ft} \ldots \ldots \ldots \ldots \ldots \ldots \ldots \ldots .60$

Stephandra flexuosa, 2 to $3 \mathrm{ft} \ldots \ldots \ldots \ldots \ldots \ldots \ldots \ldots \ldots .25$

" " 3 to $4 \mathrm{ft} \ldots \ldots \ldots \ldots \ldots \ldots \ldots \ldots . .50$

" $" 4$ to $5 \mathrm{ft} \ldots \ldots \ldots \ldots \ldots \ldots \ldots \ldots .75$
Per doz. Per 100

2.50

40.00

$7.50 \quad 60.00$

$2.50 \quad 20.00$

$5.00 \quad 40.00$

$\begin{array}{ll}2.50 & 20.00\end{array}$

$5.00 \quad 30.00$

$2.50 \quad 20.00$

$\begin{array}{ll}5.00 & 40.00\end{array}$

$2.50 \quad 20.00$

$5.00 \quad 40.00$ 
Spirea
..
Bumalda, Arguta, Billardi, Callosa, Callosa rosea,

Fortuni Macrophylla, Op. Aurea, Prunifolia, Reevesii, Reevesii fl. pl., Thunbergi and Van

Houtii, Anthony Waterer, 2 to $3 \mathrm{ft} . . . . \ldots$.

$$
3 \text { to } 4 \mathrm{ft} . \ldots \ldots \ldots
$$

4 to $5 \mathrm{ft} . \ldots \ldots \ldots$.

Tamarix, Africana or Gallica, 2 to $3 \mathrm{ft}$.

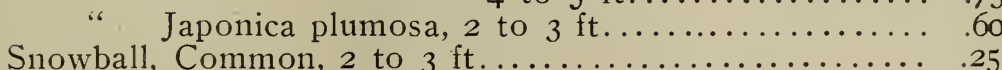

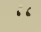

".

3 to $4 \mathrm{ft}$

4 to $5 \mathrm{ft}$.

Japa

6

2 to $3 \mathrm{ft}$.

3 to $4 \mathrm{ft}$.

4 to 5

5 to 6

Tree Form.

Tomentosum, 2 to $3 \mathrm{ft}$.

Lantana, 2 to $3 \mathrm{ft}$.

Eva

Rathka,. Candida, Floribunda, Rosea, Looymansi aurea, Montesquieu, Van Houtti and Variegated, 2 to $3 \mathrm{ft}$. 
Weigelia, Eva Rathke, Candida, Floribunda, Rosea, Looymansi aurea, Montesquieu, Van Houtti and Variegated, 3 to $4 \mathrm{ft} \ldots \ldots \ldots \ldots \ldots . .60$

Yucca fiilamentosa.

\section{CLIMBING VINES}

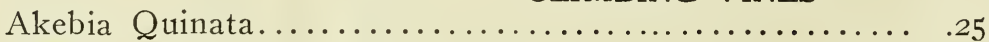

Ampelopsis Veitchi or Japan Ivy ................. .30

Aristolochia Sipho, Dutchman's Pipe............. .75

Clematis, large flowering kinds, 2 years............ .75

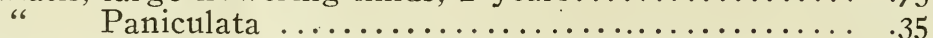

Honeysuckles, Chinese, Halls Japan, Golden, Belgian... . .25

Ivy, English Scarlet Trumpet................. . 35

$$
3.00
$$

Virginia Ceeeper or American Ivy............... .25

Wistaria, Chinese Purple...................... .50 "White

\section{HEDGE PLANTS}

Privet, California, I2 to 18 in........\$30.00 per Iooo .06

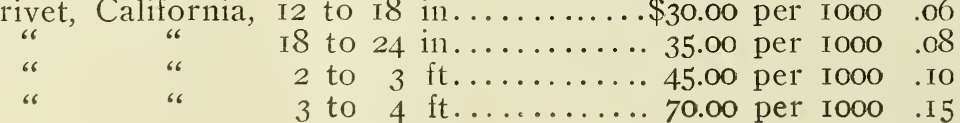

$\begin{array}{rr}.60 & 4.00 \\ .75 & 5.00 \\ 1.00 & 6.00 \\ 1.50 & 8.00\end{array}$




\section{ORNAMENTAL GRASSES.}

Eulalia Japonica, Zebrina, Gracillima.............. . .20

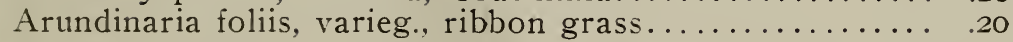

ROSES.

Climbing ..........................................

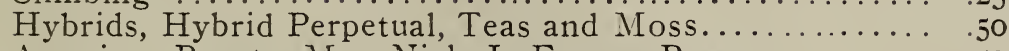

American Beauty, Mar. Niel., LaFrance, Rugosa........ . .50

Crimson, Pink, White and Yellow Rambler............35

Baby Rambler, red..........................50

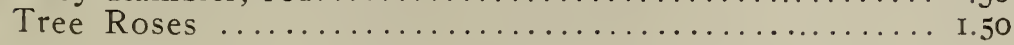

$\begin{array}{ll}2.50 & 20.00 \\ 5.00 & 40.00 \\ 5.00 & \\ 3.50 & 25.00 \\ 4.00 & 3000\end{array}$




$$
\begin{aligned}
& i \\
& 1 \\
& i \\
& i
\end{aligned}
$$

